\title{
Fan Loyalty Toward International Football Team: The Role of Brand Image
}

\author{
Dwi Irianto $^{\mathrm{a}}$, Dwi Kartikasari ${ }^{\mathrm{b}^{*}}$

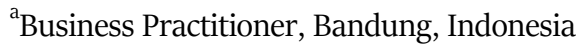 \\ ${ }^{\mathrm{b}}$ Associate Professor, Department of Applied Business Administration, Politeknik Negeri Batam, \\ Indonesia
}

Received 27 January 2020; accepted 31 January 2020

\begin{abstract}
Most studies of fan loyalty in sports marketing only focus on spectator attachment and athlete brand equity. There are not many studies examine fan loyalty formulation toward the international team using the brand image. Therefore, this study aims to examine the influence of two brand image dimensions (attributes and benefits) in creating fan loyalty toward the international football team. This study applied the covariance-based structural equation model for analyzing the data. The sample consisted of 335 Indonesian fans of the international football team. The study's results reveal that both attributes and benefits are pivotal factors in influencing fans attitudinal as well as behavioral loyalties. Further, this study also shows that the effect of attributes on attitudinal loyalty is higher compared to those on the behavioral one. These findings extend the existing knowledge on the relationship between brand image and customer loyalty in a sports context and provide useful implications for practitioners to retain their fan loyalty.
\end{abstract}

\section{KEYWORDS}

International team fans

Brand image

Attitudinal loyalty

Behavioral loyalty

Indonesia

\section{INTRODUCTION}

Football has become a fast-growing global brand commodity due to the increased sport commercialization as well as a benchmark professionalism or other types of sports (Fujak, Frawley, McDonald, \& Bush, 2018; Thompson, Martin, Gee, \& Geurin, 2018). It is indicated by the growth of fan club bases, which are not only in the country where the team originated but also from overseas (Maderer, Holtbruegge, \& Woodland, 2016). Further, the globalizing of this sport also restructures the concept of fanship, from just being a supporter of a team to becoming an integral source of club revenue (Ferrari, 2017). Thus, in this global and competitive football environment, sport management is confronting with a critical issue to get a better understanding of managing the needs of the fans. More specifically, developing and maintaining the attractiveness of a football team through team performance is a must to create long term fan loyalty toward the team (Lee, Kunkel, Funk, Karg, \& McDonald, 2019). 
Considering the benefit of having loyal fans, numerous studies have devoted to scrutinizing loyalty in various sport contexts (Martin, 2013). In terms of loyalty determinants, past studies have focused on spectators' attachment, player involvement, and fans' emotions (Foroughi, Nikbin, Hyun, \& Iranmanesh, 2016; Yoshida, Heere, \& Gordon, 2015). However, the literature seems to be silent in examining how brand image, which is widely recognized in various sports industries, gives impacts on loyalty (H. Cho, Lee, \& Pyun, 2018). Thus, how brand image influences fan's behaviour loyalty remains unclear. Therefore, scholars (Maderer et al., 2016) suggest exploring how brand image influences fan loyalty toward football club.

The attention of Asian football fans toward the international team has been proliferating due to media coverage (i.e., TV broadcast). However, the sport-literature has poorly addressed this market for a research base need (Fuller, 2015; Maderer et al., 2016). Cho (2013) argues that it is imperative to examine the behavior of Asian fans toward the international football team to generate a novelty understanding of this diverse and dynamic market. Besides, the international football fan base in Asia as a developing football market continent has recently expanded with approximately 35\% global coverage of in-home audiences (Y. Cho, 2013; Nielsen, 2017). Another consideration is that fans' behaviour in developed and developing countries cannot be generalized in the context of football. Thus, further research exploring fan loyalty toward the international football team in developing Asian countries is necessary.

This study is conducted in the Indonesian market for several reasons. The findings from Repucom (2014) reveal that Indonesia is ranked second worldwide (77\%) regarding their interest in football. This country is also in the third rank among other Southeast Asian countries regarding active community participation in football game. Specifically, The Global Web Index (2015) report also shows media consumption of Indonesian fans is the highest (54\%) among other Southern Asian countries for the English Premier League. This data have not been added to the number of fans for other European Leagues, such as Bundesliga in Germany, La Liga in Spain, Ligue 1 in France, and Serie A in Italy. These statistics show that the Indonesian international football fans' market is massive and potential. Therefore, conducting this study in the context of Indonesian fans is reasonable.

This study is set up to achieve a comprehensive understanding of the link between brand image and fan loyalty toward the international football team in a developing country. Specifically, this research has two purposes, first, to examine the link between two brand image dimensions (attributes and benefits) and fan loyalty and second, to assess the models' applicability in terms of football fans in a developing market. It seems plausible that a better understanding of fan loyalty formation can be highly beneficial for professional team management so they can formulate an effective and competitive strategy to expand fans' loyalty in a diverse market.

\section{LTTERATURE REVIEW}

\section{The Conceptualization of Fan Loyalty}

In a straightforward term, fans are groups of people who perceive themselves as supporters through intensively talking, thinking, and oriented toward something, in this case, a sports team 
(Norris, Wann, \& Zapalac, 2014). The term "fan loyalty" refers to the output of consistency and dedication to support and show a commitment to a team (Johnston, 2004). Specifically, current sports marketing literature (Maderer et al., 2016) describes the characteristics of fan loyalty in three approaches: cognitive, attitudinal and behavioral.

The first approach defines fan loyalty based on the knowledge and understanding of the team. However, this approach is not used in this study because this theory classifies fans just as spectators who see football matches as entertainment to seek enjoyment when getting involved in a game event, so they are not fully committed to the team (Shin, Lee, \& Perdue, 2018). The second approach is behavioural, which measures fans' propensity through practical action toward the team, such as the patterned arrival on the match day and the act of buying products related with the team, such as merchandises and souvenirs (D C Funk, Mahony, \& Ridinger, 2002; Martin, 2013). However, this method has been criticized due to the lack of ability to disparate loyal fans from those who give support only based on club's performance. The third approach is attitudinal, which defines loyalty as a set of commitment, emotional, and psychological attachment of a fan to the team (Carlsson, Breitbarth, \& Bjarsholmm, 2018). In sports context, this approach can also be the differentiator between the real fans and the audience (Bauer, Stokburger-Sauer, \& Exler, 2008), thus, the measurement of fan loyalty concept behaviour and attitudinal cannot be separated. Therefore, in this research, loyalty toward the international team is treated as a composite loyalty, incorporating both fans behaviour and psychological attachment.

Further, a recent study from Maderer (2016) reports a positive linkage between attitudinal and behavioural loyalty. Although this study used different bases research, it is expected that the fans' psychological attachment will lead to behavioural loyalty. Therefore, the hypothesis formulated is as follow:

$\mathrm{H}_{5}$ : Attitudinal loyalty positively influences behavioural loyalty

\section{The Conceptualization of Brand Image}

In a competitive market, the strength of brand equity becomes the foremost thing that determines the existence of a product. One of the widely reported instruments used to measure brand strength is Customer-Based Brand Equity CBBE) with brand awareness and brand image as its measurement tools (Keller, 1993). Since the concept of managing a football team as a brand has become a prevailing paradigm in the sport setting (Doyle, Filo, McDonald, \& Funk, 2013) to increase the club's potency for the goals of support and commercial, CBBE is applicable in giving useful insight for sport manager to control the mental association of their fans toward the team (Bauer et al., 2008; D C Funk et al., 2002).

To some extent, a recent study has explored and found the importance of developing and managing brand equity by professional sports team (Biscaia et al., 2016). Furthermore, sport marketing academics have identified the substance of managing brand equity for professional sports team to yield long-term fan loyalty (Brunello, 2018) through creating and maintaining their team brand image. However, most of the studies to identify factors forming fan loyalty are conducted in the European football fans market as the research base. The linkage between brand image and fan loyalty of Asian Football Fans (AFF) toward their favourite international 
teams has received limited attention in academic sports literature (Bauer et al., 2008; Maderer et al., 2016). Thus, its construction has not had a strong theoretical foundation yet. Whereas, failing to investigate those possible relations of variables in both conceptualization and operationalization would be a drawback to completely understand the applicability of brand equity construct in the fan loyalty setting in a cross-cultural context. Hence, further studies are needed to fill this research gap in order to explain the influence of brand image on attitudinal and behavioural loyalties over international team fans in the context of AFF, in this case, Indonesia.

As noted previously, CBBE measurement consists of two tools; brand image and brand awareness. However, this research deliberately did not include the measurement of brand awareness because it was irrelevant to the Indonesian market condition which already has a strong level of recognition toward their favourites' international team (Fuller, 2015). This study only measured the brand image to identify the strengths of brand equity. However, CBBE is still reliable to be the measurement tool as long as it represents consumers' thoughts about the product. The measurement of brand image consists of three dimensions: attributes, benefits, and attitudes (Bauer et al., 2008). To avoid bias results due to simultaneous measuring, this study did not incorporate the brand attitude with attitudinal loyalty which was adopted in this proposed model.

\section{Benefits}

Theoretically, benefits are a set of intangible outcomes received by consumers after consuming a product. It is classified into three parts: functional, symbolic, and experiential (Keller, 2016). Because the consumption of sporting goods is more emphasized on seeking experience and sensory rather than functional needs, this study did not assess the functional benefit since it was not relevant (Bauer et al., 2008). The indicator for symbolic benefit is pride which can be defined as the level of self-importance and association felt by fans related to the capability of the team to create the pride place and country it represents (Maderer et al., 2016). Meanwhile, the indicators of experiential benefit are nostalgia, escape, and socializing/companionship. The first indicator means the ability to evoke beautiful memories from what fans have felt when giving support to their favourite club (Bauer et al., 2008; Brunello, 2018). The second indicator shows the benefit felt by the fans to help them rest from various tiring activities (leisure) (Bauer et al., 2008). Meanwhile, the third indicator is about the relationship between fans (Bauer et al., 2008).

Scholars widely report that the dimension of benefits is critical and has a significant impact to influence costumers' behavioural loyalty (Bauer et al., 2008). The benefit of supporting a football team also highlights the interaction between the team and fans, directly or indirectly. Thus, it provides psychological and emotional attachment between fans and the team, which is called attitudinal loyalty. Therefore, benefit has a vital factor to determine both psychological attachment and empirical action which are shown through purchasing product-related with the team (Maderer et.al., 2016). 


\section{Attributes}

Attribute in a sports context refers to anything that is directly or indirectly related to the performance of a team (Keller, 2016). Specifically, the attribute can be classified into two; product-related and non-product-related attributes. The product-related attribute is everything that sticks to team characteristics and directly affects the performance of the team (Brunello, 2018). A recent study of Maderer et al. (2016) measured the product-related attribute with club success, star players, club manager, and front office. However, this study replaced the front office indicator with the team's game because the later was considered more actual and directly affected the game. Meanwhile, the non-products-related attribute is everything inherent to the team but not directly affects its performance. It is measured by management, club emblem, stadium, club achievement, and history (Daniel C Funk \& James, 2006; Maderer et al., 2016). Based on the proposed model, the researcher adopts this theory as the dimensions to measure the non-product-related attributes because it is considered fully representative (Brunello, 2018).

Literature finds out the significant impact of brand attributes in forming loyalty (Durmaz, Cavusoglu, \& Ozer, 2018). However, in a sports context, there is an incongruity result of this causality. Maderer et al. (2016) explain that attributes have a significant adverse effect on fan loyalty. On the contrary, Bauer's (2008) empirical study conducted in other sports literature reveals that attribute has a significant favorable impact in forming fan loyalty, both attitudinal and behavioural. The last literature is in line with the majority of scholars who agree that fan loyalty in a sports context is more influenced by product-related attributes (Anagnostopoulos, Parganas, Chadwick, \& Fenton, 2018).

From the explanation regarding benefits and attributes above the hypotheses are as follows:

$\mathrm{H}_{1}$ : Attributes positively influence attitudinal loyalty

$\mathrm{H}_{2}$ : Benefits positively influence attitudinal loyalty

$\mathrm{H}_{3}$ : Attributes positively influence behavioural loyalty

$\mathrm{H}_{4}$ : Benefits positively influence behavioural loyalty

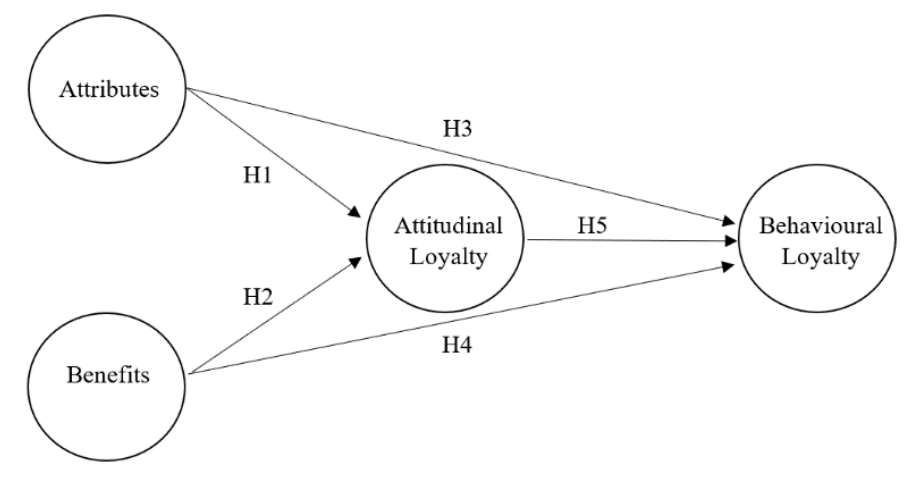

Figure 1. Proposed model

The research model above was adopted from the previous study from Maderer et.al (2016) which explain the linkage between the dependent variable and independent variable in the sport marketing context. In that model, variable attributes and benefits play as variable independent 
toward variable attitudinal loyalty which play as variable dependent. Further, this model also explains the possible linkage between variable attitudinal loyalty which play as variable independent toward behavioral loyalty as variable dependent.

\section{RESEARCH METHODS}

To test the intended research model, this study involved international team fans. Specifically, this study used a sample of Indonesian fans of the international football team. Indonesia is one of the biggest markets for many international teams and a country with great local football culture. As this study is aimed to examine fan loyalty toward international football team in Asian football fans, it is reasonable to collect data from Indonesian fans.

The data were collected in June 2017 through an online questionnaire to the fans club's social media of the international football team. To ensure the questionnaire was distributed to the intended respondents, the respondents were asked prior to filling in the questionnaire; whether they were a fan or just a spectator. There were 335 questionnaires distributed; none of them was excluded from the analysis because all of the respondents filled in the questionnaire completely. The number of respondents filling in the questionnaire had been targeted at least 370 respondents because the population of football fans in Indonesia is approximately 10.000 people.

This study adapted the items from previous researches to measure the construct of fan loyalty using Costumer-Based Brand Equity (CBBE). Attributes and benefits were used as the dimensions of brand equity. The attributes variable consists of 8 indicators which were measured by three items adapted from the work of Bauer et al. (2008). Meanwhile, following Maderer et al. (2016), the benefits variable built-up by three indicators which were also measured by three items. This study also included fan attachment due to the characteristics of Indonesian people who have a high value of collectivism (Hofstede, 2001) that added up to 4 indicators for the benefits variable. Moreover, fan loyalty is a composite loyalty that involves attitudinal and behavioural loyalties. Attitudinal loyalty was measured by using the Psychological Commitment Team adopted from previous studies (PCT) by (Maderer et al., 2016; Mahony, Madrigal, \& Howard, 200o). Similarly, behavioural loyalty was adopted from Maderer et al. (2016). All cases were measured by five questions rated by a 5-point Likert-type scale ( 1 for "very disagree" and 5 for "very agree").

The data were analysed using covariance-based structural equation modelling (CBSEM). This study did not conduct the confirmatory factor analysis (CFA) to validate the proposed models because the construct and items used had been tested empirically (Maderer et al., 2016). Thus, the usage of this type of SEM is suitable as this research was proposed to confirm a theory (Hair, Hult, Ringle, \& Sarstedt, 2014).

Table 1. Scale measurement and its resources

\begin{tabular}{clc}
\hline No. & Construct & \multicolumn{1}{c}{ Sources } \\
\hline 1. & Fan Loyalty & \\
2. & Attributes & (Maderer et al., 2016) \\
3. & Benefits & \\
\hline
\end{tabular}




\section{RESULTS}

This research involved 335 respondents of international football team fans. On average, those fans have been supporting their favourite teams over the past five years, with the percentage of international team fans above $70 \%$. This result shows that the sample of this study is dominated by fans who have been supporting the team for a long time. The gender of respondents is dominated by male fans with a percentage close to $95 \%$. Most of the respondents are in the range of 25 to 35 years. This fact indicates that supporters of international teams are teenagers and young adults, not people over 36 years. This finding is in line with the data published by Repucom (2014) regarding the characteristics of Global Football Fan. It shows that the majority of the fan is male with the age range between 25-34 years old. Besides, the demographic characteristic data also confirm the consumption pattern of Indonesian society within that age range which tends to enjoy football broadcasts merely as entertainment media. In other words, there is no fanatical supportive tendency towards any club in the society of that age group.

\section{Measurement Model}

It is imperative to assess construct validity based on a convergent and discriminant approach before evaluating a study on the structural model more comprehensively for the reliability of the model. This study assessed the convergent validity test using factor loading and average variance extracted (AVE) factors. Scholars note that a variable is considered to be valid and significant if the coefficient value from the construct is above 0.5. The Table 1 below demonstrates that all dimensions in international fans have both loading and AVE factors above the definite criteria. The reliability was evaluated by Cronbach $\alpha$ as the common measurement to assess reliability and composite reliability test of a construct. Further, coefficient $\alpha$ for each variable shows the value above cut-off value (0.7) for every dimension. In line with $\alpha$, composite reliability has value above the criteria 0.7 .

Table 2. Validity and reliability results

\begin{tabular}{lcccc}
\hline & Loading & CR & AVE & $\alpha$ \\
\hline Attributes & & 0.891 & 0.508 & 0.802 \\
Success & 0.669 & & & \\
Player & 0.736 & & & \\
Game Play & 0.763 & & & \\
Coach & 0.780 & & & \\
Management & 0.567 & & & \\
Emblem & 0.760 & & & \\
Stadium & 0.781 & & & \\
Tradition & 0.615 & & & \\
Benefits & & 0.879 & 0.645 & 0.828 \\
Pride in Place & 0.754 & & & \\
Fans attachment & 0.819 & & & \\
Escape & 0.813 & & & \\
Nostalgia & 0.824 & & & \\
Attitudinal Loyalty & & 0.963 & 0.838 & 0.952 \\
Behavioral Loyalty & & 0.827 & 0.547 & 0.737 \\
\hline
\end{tabular}




\section{Structural Model}

This research applied SmartPLS 3.0 for analysing the structural model and testing the hypotheses. This study applied Hair et al., (2014) who suggest using the bootstrapping method with 500 repetitions. Formula calculation of the average $\mathrm{R}^{2}$ for endogenous constructs and the geometric mean of the communality was applied to measure goodness-of-fit index (GoF) as recommended by Cohen (1988). He notes that GoF value is classified into 3 dot intervals: 0,10 is considered small, 0.25 is considered medium, and 0.36 is considered large. GoF formulation measurement in this study produces a value of 0.556 for international team fans (see Table 2). It indicates that the data are proper to explain the proposed model.

Chin et al. (2008) suggest that researchers can use the magnitude of $\mathrm{R}^{2}$ and the predictive sample reused technique Stone-Geisser's $\mathrm{Q}^{2}$ value as the standards for the predictive significance of testing model using PLS. $\mathrm{Q}^{2}$ specifies how well the data can be restructured using the model and the parameters of PLS. Hair et al. (2014) classify the cut-off value of $Q^{2}$. $Q^{2}$ value larger than o indicates the relevance of the tested model and $\mathrm{Q}^{2}$ value less than o indicates the lack of predictive value. $\mathrm{Q}^{2}$ calculation yields for international team fans are 0,468 (attributes), 0.605 (benefits), 0.397 (attitudinal loyalty), and 0.212 (behavioral loyalty), representing that this study has acceptable predictive relevance.

Chin et al. (2008) on their formulation also note that the $\mathrm{R}^{2}$ values of endogenous latent variables can be categorized into three groups: weak (o.19), moderate (0.33), and substantial (o.67). Referring to these classifications in the case of international football team fans, attitudinal loyalty $\left(\mathrm{R}^{2}=0.524\right)$ is between moderate and substantial, similar case also happens for behavioural loyalty $\left(\mathrm{R}^{2}=0.450\right)$ which is also between moderate and substantial. This study reveals that in the context of international football team fans, the attributes and benefits explain attitudinal loyalty closer to substantial. Meanwhile, the explanatory power of attributes and benefits toward behavioural loyalty is the closest meaning to substantial.

Hypotheses $\mathrm{H}_{1}-\mathrm{H}_{5}$ suggest the relationships between attributes and benefits toward attitudinal and behavioural loyalties. Table 3 shows that for international football team fans, attributes have a significant influence on both attitudinal loyalty (0.563) and behavioural loyalty $(0,241)$ with $\mathrm{p}<0,01$. Meanwhile, benefits also have significant value and positively influence the attitudinal and behavioural loyalties (coefficient 0.212 and 0.448 ) with $\mathrm{p}<0.01$ ). In addition, attitudinal loyalty has a positive value and significant impact towards behavioural loyalty (o.311) at $\mathrm{p}<0.01)$. Thus, it can be concluded that all of the hypotheses $\left(\mathrm{H}_{1}-\mathrm{H}_{5}\right)$ are confirmed.

Table 3. Goodness-of-fit index

\begin{tabular}{lcccc}
\hline & AVE & $\mathrm{Q}^{2}$ & $\mathrm{R}^{2}$ & GoF calculation \\
\hline Attributes & 0.508 & 0.468 & & \\
Benefits & 0.645 & 0.605 & & \\
Attitudinal Loyalty & 0.838 & 0.397 & 0.524 & \\
Behavioral Loyalty & 0.547 & 0.212 & 0.540 & \\
$\quad$ Average score & 0.634 & & 0.487 & \\
$\quad$ AVE x R & & & & 0.309 \\
$\mathrm{GoF}=\sqrt{\left(A V E \times R^{2}\right)}$ & & & & 0.556 \\
\hline
\end{tabular}




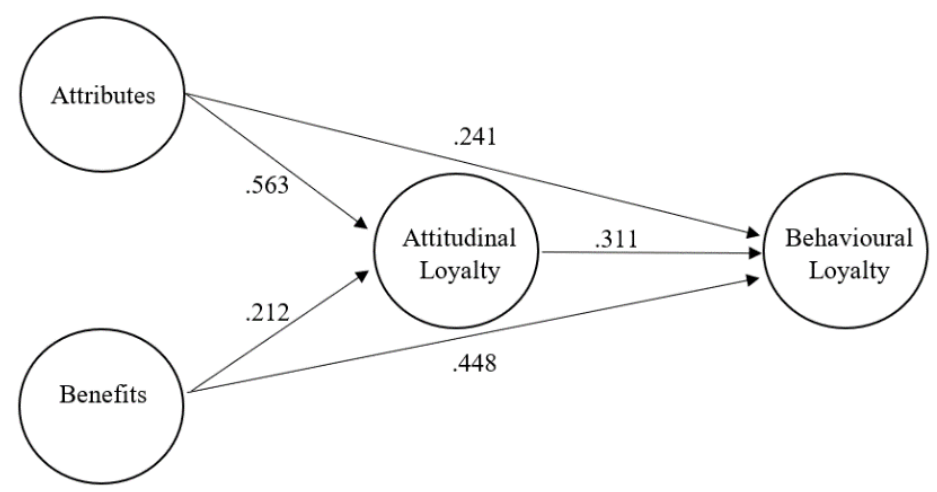

*Significant at $p<0,05$

Figure 2. The structural research model

Table 4. Hypotheses testing

\begin{tabular}{|c|c|c|c|}
\hline & Coefficient & t-value & Result \\
\hline \multicolumn{4}{|l|}{ Attributes } \\
\hline Success $\rightarrow$ Attributes & 0.163 & 13.902 & \\
\hline Player $\rightarrow$ Attributes & 0.184 & 15.154 & \\
\hline Game Play $\rightarrow$ Attributes & 0.186 & 13.918 & \\
\hline Coach $\rightarrow$ Attributes & 0.209 & 13.543 & \\
\hline Management $\rightarrow$ Attributes & 0.131 & 8.820 & \\
\hline Emblem $\rightarrow$ Attributes & 0.184 & $13 \cdot 522$ & \\
\hline Stadium $\rightarrow$ Attributes & 0.196 & 13.046 & \\
\hline Tradition $\rightarrow$ Attributes & 0.135 & 13.857 & \\
\hline \multicolumn{4}{|l|}{ Benefits } \\
\hline Pride $\rightarrow$ Benefits & 0.305 & 23.297 & \\
\hline Fans $\rightarrow$ Benefits & 0.320 & 24.104 & \\
\hline Escape $\rightarrow$ Benefits & 0.320 & 22.744 & \\
\hline Nostalgia $\rightarrow$ Benefits & 0.301 & 22.433 & \\
\hline \multicolumn{4}{|l|}{ Attributes $\rightarrow$ Fan Loyalty } \\
\hline $\mathrm{H}_{1}$ : Attributes $\rightarrow$ Attitudinal Loyalty & 0.563 & $6.612^{* *}$ & Supported \\
\hline $\mathrm{H}_{3}:$ Attributes $\rightarrow$ Behavioral Loyalty & 0.241 & $2.921^{\star *}$ & Supported \\
\hline \multicolumn{4}{|l|}{ Benefits $\rightarrow$ Fan Loyalty } \\
\hline $\mathrm{H}_{2}$ : Benefits $\rightarrow$ Attitudinal Loyalty & 0.212 & $3.538^{* *}$ & Supported \\
\hline $\mathrm{H}_{4}$ : Benefits $\rightarrow$ Behavioral Loyalty & 0.448 & $6.104^{* *}$ & Supported \\
\hline \multicolumn{4}{|l|}{ Fan Loyalty } \\
\hline $\mathrm{H}_{5}:$ Attitudinal Loyalty $\rightarrow$ Behavioral Loyalty & 0.311 & $3.409^{* *}$ & Supported \\
\hline
\end{tabular}

\section{DISCUSSION}

First, this study reveals that attributes have a positive and significant influence on both attitudinal and behavioural loyalty. This result is in line with the previous studies that notify attributes to play an integral role in the formation of attitudinal loyalty (Carlsson et al., 2018; 
Lee et al., 2019). This finding, however, contradicts Maderer et al. (2016)'s finding in emerging market football context which says that attributes have a negative influence on attitudinal loyalty. The importance of brand attributes on attitudinal loyalty suggests that star players, the success of the team, and the quality of the game give impacts on fans' psychological commitment. Thus, in line with the previous research by Anagnostopoulos et.al (2018), sports marketers need to specifically emphasize their product-related attributes which significantly shape and encourage greater engagement for the worldwide audiences in their further buildbranding processes. Meanwhile, this study also confirms that attributes of the team affect the future behaviour of fans (Biscaia et al., 2016). This finding suggests that attributes have a significant role in determining the pattern of watching the team game and purchasing team merchandise. However, as previously noted by scholars (Lee et al., 2019), on-field team performance is a factor beyond the ability to be managed and controlled by the sports marketer. Consequently, they have to pay more attention to off-field aspects such as the official team board or management in creating positive service quality experience for their fans (Gholizadeh, Talebpour, Kashtidar, \& Abdolmaleki, 2018).

Second, this study contributes to providing reliable support for Yoshida et.al (2015) and Biscaia et al. (2016) researches which find the significant linkage between benefits and behavioural loyalty. This result notes, although the fan's location is far from the football club origin, the benefits gained such as experiential and involvement with the team can arise from the activities with other fans, before, during, and after the match. This result is in line with the finding of Lada et.al (2018) who find the experiential and symbolic benefits as the determinant factors shaping fan loyalty. Behavioural loyalty mostly comes from the experience and emotional bonding among fans as a result of enjoying match games together which allows them to foster socialization and get the desire to stay and sing their club anthem together $(\mathrm{H}$. Cho et al., 2018; Lada et al., 2018). Even without direct attendance of international fans to the stadium, this study suggests that the brand benefits affect behavioural loyalty from international fans' standpoint. Thus, sports marketers need to utilize fans' engagement within the community through various events and combine them with excellent media campaigns (Santos, Guardia, Campos, Calabuig-Moreno, \& Ko, 2018). Thus, it will make the fans willing to support the team faithfully in the long run and make a purchase of related-brand products. As noted by Lada et.al (2018) and Wear et.al (2018), experiential benefits can be imperative to deepen loyalty. Therefore, besides ensuring the availability of qualified squad, understanding how to develop marketing strategies aimed at increasing the team brand relationship is another task to be done.

Further, this study also finds a significant linkage between benefits and attitudinal loyalty. This finding is in line with the study of Maderer et al. (2016) who reveal that benefit is the driving force of attitudinal loyalty. These results claim that a range of benefits that the spectators get, such as leisure, the interaction between fans, nostalgia, and the time spent with fun activities can collectively improve their commitment toward the football team (Florea, Barbu, \& Barbu, 2017; Tachis \& Tzetzis, 2015).

Third, although both attributes and benefits are essential determinants of attitudinal and behavioral loyalties, their degrees of impacts are different. Attributes have more significant impacts on attitudinal loyalty than benefits to behavioral loyalty. This result is in line with the literature that reveals that fans tend to create attitudinal loyalty from the attributes of their professional sports team as the impact of internationalization (Maderer \& Holtbrugge, 2018). 
Whilst, due to geographic distance, overseas fans prefer continuously supporting their favorite team because of benefits offered which eventually create behavioral loyalty (Durmaz et al., 2018). Furthermore, the factors behind regularly watching team matches and purchase relatedproducts are caused by the possibility to cultivate value congruence and foster social interaction/relationship between fans and their favorite teams (Biscaia et al., 2016).

Meanwhile, the dimensions such as star player and head coach tend to create attitudinal loyalty (Biscaia et al., 2016; H. Cho et al., 2018). This is because attributes become the first that comes to fans' minds through the intrinsic aspects that inherent with the club because of the geographic distance (Maderer et al., 2016). Therefore, their psychological attachment with those extrinsic factors plays an integral role in shaping supportive attitudes toward the club (Biscaia et al., 2016). This research also reveals the relationship between attitudinal loyalty and behavioral loyalty which aligns with the previous study (Tachis \& Tzetzis, 2015). The results indicate that the manifestation of a team brand image can establish behavioral loyalty in the form of buying merchandise and consuming products related to the team (Keshtidar, Sahebkaran, Talebpour, \& Kalashi, 2018; Maderer et al., 2016). In other words, in the future, the behavioral loyalty of the spectators is built based on the teams' ability to enhance a psychological commitment to their fans.

Fourth, this research has succeeded in finding empirical evidence of the model applicability for assessing brand equity as a measurement tool in terms of fan loyalty in a developing market. It is indicated by the construct that shows good validity and reliability within a specific study of fan loyalty in the Indonesia football market. Besides, this result also strengthens the applicability of Costumer-Based Brand Equity (CBBE) to measure loyalty in different settings. Thus, this study can be a reference since it provides a new understanding of what approaches to be applied in order to create and develop fan loyalty based on the measurement of this construct.

\section{MANAGERIAL IMPLICATION}

This study presents fruitful and valuable practical implications for international team managers in football industries to develop and foster fan loyalty. This study underlines that, for international team fans, attributes become the most significant factor in creating attitudinal loyalty. It means that the managers should concentrate on everything that is directly related to the performance of the club (e.g. successes, star player, and head coach). Therefore, in every season, the club managers have to ensure that they recruit qualified players, play entertaining matches, and are supported by qualified coaches.

Moreover, several approaches, such as keeping in touch indirectly through social media, setting up club fan bases, and planning pre-season tours in order to create an attractive event to connect both fan club and the team itself, would be plausible options to do. The manager needs to consider the importance of supporter communality association since a shared group association through continuous interaction creates a more significant impact on loyalty. Furthermore, managing the online brand community will lead to a positive effect on social branding engagement (Yoshida, Gordon, Nakazawa, Shibuya, \& Fujiwara, 2018). Eventually, those efforts are to stimulate tangible actions to purchase products/services provided by the team, enable sports managers to build an integrated brand marketing strategy, and increase 
psychological attachment. That will build fans' prestige and loyalty toward the team they support.

The findings also reveal that fans' behavioural loyalty is significantly affected by benefits association. It means that club management should keep its global fans in touch with various activities to enhance direct-indirect interaction between the team and its fans, such as preseason tours periodically, developing team membership for regional-based supporters, and active interaction to inform the latest news about the team through social media. To ensure the applicability of these strategies, having an official representative to deliver direct communication and provide a field for any exhibition or event-related to a club is essential. Besides, due to massive attention from Indonesian fans toward the international football team, the official opening of merchandise selling of a team in the capital cities in Indonesia is reasonable to trigger more buying intention and generate revenue for the club. Eventually, these activities would trigger personal experience and develop emotions from overseas fans.

\section{LIMITATION AND FUTURE RESEARCH}

Although this study offers a number of imperative contributions to sports marketing academics and sports management, it surely has a number of limitations. First, this study was conducted in the Indonesian football market. It does not guarantee similar findings if the model is tested in the different settings of the Asian football market. Second, the sample in this research, although purposively drawn from the international team fans in Indonesia, does not fully represent fans at all international teams in the European clubs. Future research needs to gather more heterogeneous fans that supporting more diverse international teams' and other European football clubs to ensure the representativeness of Indonesian international fans as a whole. Third, the model tested in this study used attributes and benefits as determinant variables that influence attitudinal and behavioral loyalty. However, this proposed model has not measured the causal relationship between the variables of attributes and benefits. Consequently, the possible causal effect between those variables cannot be detected. Future researchers are suggested to put this on concern to provide deeper insight and examine the possibilities of how attributes variables affect benefits. It will expand the theoretical perspective and broaden managerial practice to formulate strategies for enhancing the benefits associations of a team through attributes variables.

\section{REFERENCES}

Anagnostopoulos, C., Parganas, P., Chadwick, S., \& Fenton, A. (2018). Branding in pictures: Using instagram as a brand management tool in professional team sport organisations. European Sport Management Quaterly, 18(4), 413-438. doi: 10.1080/16184742.2017.1410202

Bauer, Stokburger-Sauer, N. E., \& Exler, S. (2008). Brand image and fan loyalty in professional team sport: a refined model and empirical assessment. Journal of Sport Management, 22, 205-226.

Biscaia, R., Ross, S., Yoshida, M., Correia, A., Rosado, A., \& Maroco, J. (2016). Investigating the role of fan club membership on perceptions of team brand equity in football. Sport Management Review, 19(2), 157-170. doi: 10.1016/j.smr.2015.02.001

Brunello, A. (2018). Brand equity in sports industry. International Journal of Communication Research, 8(1), 25-30. 
Carlsson, B., Breitbarth, T., \& Bjarsholmm, D. (2018). Measuring consumer based athlete brand equity and its relations with identification, consumer behaviour and attitudinal loyalty Managing Sport in A Changing Europe: The European Sport Management Conference. Malmo: Department of Sport Sciences, Malmo University.

Cho, H., Lee, H., \& Pyun, D. (2018). The influence of stadium environment on attendance intentions in spectator sport: The moderating role of team loyalty. International Journal of Sports

Marketing and Sponsorship. doi: 10.1108/IJMS-04-2017-0025

Cho, Y. (2013). Introduction: football in Asia. Soccer \& Society, 14(5), 579-587. doi: 10.1080/14660970.2013.792478

Doyle, J., Filo, K., McDonald, H., \& Funk, D. (2013). Exploring sport brand double jeopardy: The link between team market share and attitudinal loyalty. Sport Management Review, 16(3), 285-297. doi: /10.1016/j.smr.2012.11.001

Durmaz, Y., Cavusoglu, S., \& Ozer, O. (2018). The effect of brand image and brand benefit on costumer loyalty: The case of Turkey. Academic Research in Business \& Social Science, 8(5), 528540. doi: 10.6007/IJARBSS/v8-i5/4140

Ferrari, S. (2017). Traditional and mediatized soccer fanship: the case of Indonesian Juventus' supporters. Soccer \& Society. doi: 10.1080/14660970.2017.1357032

Florea, D.-L., Barbu, C. M., \& Barbu, M. C. R. (2017). A model of fans' reaction to resurrected brands of sport organisations. International Journal of Sports Marketing and Sponsorship, 19(2), 127146. doi: 10.1108/IJSMS-08-2017-0073

Foroughi, B., Nikbin, D., Hyun, S. S., \& Iranmanesh, M. (2016). Impact of core product quality on sport fans' emotions and behavioral intentions. International Journal of Sports Marketing and Sponsorship, 1ך(2), 110-129. doi: 10.1108/IJSMS-04-2016-010

Fujak, H., Frawley, S., McDonald, H., \& Bush, S. (2018). Are sport consumers unique? consumer behavior within crowded sport markets. Journal of Sport Management, 32, 362-375. doi: 10.1123/jsm.2017-0318

Fuller, A. (2015). Approaching football in Indonesia. Soccer \& Society, 16(1), 140-148. doi: 10.1080/14660970.2014.954387

Funk, D. C., \& James, J. D. (2006). Consumer loyalty: the meaning of attachment in the development of sport team allegiance. Journal of Sport Management, 2O(2), 189-217. doi: 10.1123/jsm.20.2.189

Funk, D. C., Mahony, D. F., \& Ridinger, L. L. (2002). Characterizing consumer motivation as individual difference factors: Augmenting the sport interest inventory (SII) to explain level of spectator support. Sport Marketing Quarterly, 11, 33-43.

Gholizadeh, B., Talebpour, M., Kashtidar, M., \& Abdolmaleki, H. (2018). Mouth advertising, an effective tool for loyalty of sport customers, case study: Women's health clubs in Mashhad. International Journal Leisure and Tourism Marketing, 6(1), 51-64. doi: 10.1504/IJLTM.2018.10009969

GlobalWebIndex. (2015). Premier League Fans Summary. Retrieved from https://insight.globalwebindex.net/hs-fs/hub/304927/file-2593818997-

Hair, J. E., Hult, G. T., Ringle, C. M., \& Sarstedt, M. (2014). A primer on partial least squares structural equation modeling (PLS-SEM). Los Angeles, CA: Sage.

Hofstede, G. (2001). Culture's consequences: Comparing values, behaviors, institutions, and organizations across nations (2nd ed.). Beverley Hills, CA: Sage Publications.

Johnston, D. (2004). Consumer Loyalty Amongst Sport Fans: AGF Case Study. (Thesis (Master Program)), Aarhus University, Aarhus, Denmark.

Keller, K. L. (1993). Conceptualizing, measuring and managing customer-based brand equity. Journal of Marketing, 5†(1), 1-22.

Keller, K. L. (2016). Reflections on customer-based brand equity: perspectives, progress, and priorities. AMS review, 6(1-2), 1-16. doi: 10.1007/s13162-016-0078-z 
Keshtidar, M., Sahebkaran, M. A., Talebpour, M., \& Kalashi, M. (2018). Investigating the effect of brand identity and character on brand loyalty of football team fans. International Journal Sport Management and Marketing, 18(1/2), 105-115. doi: 10.1504/IJSMM.2018.091344

Lada, S., Rizal, H., William, J. J., Suki, N. M., Rahman, R. A., \& Tanakinjal, G. H. (2018). Brand image benefits and satisfaction: Roles of symbolic, functional, social and experiential benefits. Labuan Journal of Muamalat and Society, 12, 178-188.

Lee, M. A., Kunkel, T., Funk, D. C., Karg, A., \& McDonald, H. (2019). Built to last: Relationship quality management for season ticket holders. European Sport Management Quaterly. doi: 10.108o/16184742.2019.1613438

Maderer, D., Holtbruegge, D., \& Woodland, R. (2016). The impact of brand associations on brand loyalty in the football industry: a comparison of fans from developed and emerging football markets. Sport, Business, and Management: An International Journal, 6(5). doi: 10.1108/SBM-o62016-0026

Maderer, D., \& Holtbrugge, D. (2018). International activities of football clubs, fan attitudes and brand loyalty. Journal Brand Management. doi: 10.1057/s41262-018-0136-y

Mahony, D. F., Madrigal, R., \& Howard, D. (2000). Using the Psychological Commitment to a Team (PCT) scale to segment sport consumer based on loyalty. Sport Marketing Quarterly, 9, 15-25.

Martin, C. A. (2013). Investigating National Football League (NFL) fan loyalty. Journal of Marketing Development and Competitiveness, $7(1), 42-53$.

Nielsen. (2017). Commercial Trends in Sport 2017 Retrieved from http://nielsensports.com/commercial-trend-sports/

Norris, J. I., Wann, D. L., \& Zapalac, R. K. (2014). Sport fan maximizing: following the best team or being the best fan? Journal of Consumer Marketing, 32(3), 157-166. doi: 10.1108/JCM-02-20140856

Repucom. (2014). World Football: From consumption to sponsorship: How fans are changing the commercial landscape of the beutiful game. Retrieved from www.nielsensport.com/worldfootball/

Santos, M. A. D., Guardia, F. R., Campos, C. P., Calabuig-Moreno, F., \& Ko, Y. J. (2018). Engagement in sports virtual brand communities. Journal of Business Research, 33(12), 273-279. doi: 10.1016/j.jbusres.2017.12.053

Shin, H., Lee, H., \& Perdue, R. R. (2018). The congruity effects of commercial brand sponsorship in a regional event. Tourism Management, 67, 168-179. doi: 10.1016/j.tourman.2018.01.016

Tachis, S., \& Tzetzis, G. (2015). The relationship among fans' involvement, psychological commitment, and loyalty in professional team sports. International Journal of Sport Management, Recreation, \& Tourism, 18, 1-25. doi: 10.5199/ijsmart-1791-874X-18a

Thompson, A.-J., Martin, A. J., Gee, S., \& Geurin, A. N. (2018). Building brand and fan relationships through social media. Sport, Business, and Management: An International Journal, 8(3), 235-256. doi: 10.1108/SBM-04-2017-0024

Wear, H., Hills, S., Heere, B., \& Walker, M. (2018). Communal brand associations as drivers of team identity and consumer behaviour. Journal of Global Sport Management. doi: 10.1080/24704067.2018.1432990

Yoshida, M., Gordon, B. S., Nakazawa, M., Shibuya, S., \& Fujiwara, N. (2018). Bridging the gap between social media and behavioural brand loyalty. Electronic Commerce Research and Applications. doi: 10.1016/j.elerap.2018.02.005

Yoshida, M., Heere, B., \& Gordon, B. S. (2015). Predicting behavioral loyalty through community: why other fans are more important than our own intentions, our satisfaction, and the team itself. Journal of Sport Management, 29(3), 318-333. 